\title{
Imaging Technique
}

National Cancer Institute

\section{Source}

National Cancer Institute. Imaging Technique. NCI Thesaurus. Code C17369.

Any technology or method that aids in the visualization of any biological process, cell, tissue or organ for use in screening, diagnosis, surgical procedures or therapy. 